\title{
Assessment of Soil Loss Rates in Asreh Watershed (North Jordan Badia) Using RUSLE and GIS
}

\author{
Saad M. AlAyyash
}

\begin{abstract}
In arid lands, rainwater harvesting can play an important role in making more water available since most of the rainfall runoff evaporates. If rainwater can be collected, it will form a useful resource. Jordan is classified as one of the poorest countries regarding water resources with an arid and semi-arid climate. For these limited and vital sources of water, good estimation of rainfall runoff quantity and quality can enhance the sustainability of water harvesting projects. The hydrologic estimations of runoff quantities and qualities are essential, and several techniques to achieve that exist. Revised Universal Soil Loss Equation (RUSLE) is one of the widely used techniques to assess the soil erosion due to runoff, by assessing other physical factors that affect the soil loss. RUSLE combined five parameters to identify the soil loss rate: rainfall erosivity, topographic, soil erodibility, vegetation cover and management, and land management. Based on RUSLE results, areas are classified as a highly soil loss rate if the annual rates exceeded 20 tons per hectare. The Asreh watershed is a $196 \mathrm{~km}^{2}$ area that is mostly wasted land and receives an annual rainfall between 50 and $300 \mathrm{~mm}$ per year. The RUSLE equation inputs parameters for the study area are found and the equation is applied for the watershed. Results of RUSLE application on the Asreh watershed showed that the average annual soil loss rate is about 7.8 tons per hectare, about $73 \%$ of the area are classified as low soil loss rate with less than 10 tons per hectare per year, and only $13 \%$ of the area is classified as a high soil loss rate of more than 20 tons per hectare per year.
\end{abstract}

Index Terms-Jordan, soil loss rate, rainwater harvesting, RUSLE, arid land.

\section{INTRODUCTION}

Jordan is classified as one of the poorest countries regarding water resources with an arid and semi-arid climate. Limited water resources, mainly precipitation, imposes pressure on national organizations to manage the available water resources and sustainably use these resources. The growing demand for water highlighted the need to use new resources and release some of the pressure on the over utilized resources.

Rainwater harvesting can play an important role in making more water available, since most of the rainfall runoff evaporates. If rainwater can be collected, it will form useful resource. A good estimation of rainfall runoff quantity and quality can enhance the sustainability of any water harvesting project. The hydrologic estimations of runoff quantities and qualities are essential for the success of water harvesting system, mainly in the arid lands where the environment is precarious [1].

Desert dams are designed to collect intermittent rainfall

Manuscript received January 30, 2020; revised November 11, 2020.

Saad M. AlAyyash is with the College of Engineering, Al al-Bayt University, Mafraq 25113, Jordan (e-mail: saad.a@aabu.edu.jo). runoff that comes in few storm events that form flush floods. The flush floods on arid lands combined with bare soil with limited vegetation carry high concentrations of sediments that limit the efficiency of water harvesting systems in the arid lands. The good management of watersheds in the arid lands can limit the erosion volumes with flush flood and increase the efficiency of water harvesting systems in these areas. To demonstrate efficient management of watersheds to limit the erosion, identifying vulnerable areas for erosion will be the first step in this process [2], [3].

The Revised Universal Soil Loss Equation (RUSLE) is widely used to identify the potential for soil erosion due to geophysical, climatological, and human practice factors [4]. The RUSLE combined five parameters, to identify the soil loss rate. The five parameters are rainfall erosivity, topographic, soil erodibility, vegetation cover and management, and land management. Based on RUSLE results, areas are classified for water erosion risk from low with annual soil loss rate $<10$ tons per hectare to high with annual soil loss rate $>20$ tons per hectare [5]-[8].

In recent years, Geographic Information System (GIS) and Remote Sensing (RS) provided helpful tools to manage and process geographic data more easily and efficiently. GIS can handle large amounts of data with geographic reference and arrange these data for many calculations in a short time, while RS can provide detailed information for large areas needed in environmental modeling. These techniques are combined to use in the process of RUSLE map creation in a pixel scale to produce spatial mapping of soil loss over large area and setting up options to locate erosion prone areas within the watersheds [6]-[18].

The objective of this work, the RUSLE equation is used to estimate the potential soil loss within the Asreh Dam Watershed. The analysis and mapping of soil loss and RUSLE factors will be done within a GIS environment (ArcGIS 10.2) and using RS data for some of the equation inputs to generate the soil erosion map.

\section{Materials And Methods}

The main goal of this study is to map the soil loss rate in the Asreh Dam Watershed and estimate the average annual sediment loads the dam will receive; the methodology to complete this study will include the following:

- Collecting the rainfall and geophysical data for the study watershed; these data include average annual rainfall, topography, soil classification, land use, and land (LULC);

- Processing the collected data to derive the RUSLE equation factors maps in a digital raster format with same referencing and resolution parameters to allow spatial 
analysis and calculation;

- Calculating the soil loss rate using the RUSLE equation from the input parameters maps and developing a soil loss map for the watershed; this map is then used to classify the soil loss risk for water erosion.

\section{A. Study Area}

The study area is located in the northeastern parts of Jordan; it covers about $196 \mathrm{~km}^{2}$ as the watershed of the Asreh Dam. The watershed extended from the dam site at $32^{\circ} 05^{\prime} 37.8^{\prime \prime} \mathrm{N}$ $36^{\circ} 50^{\prime} 45.6^{\prime \prime} \mathrm{E}$ to the upper part of the watershed in the north at $32^{\circ} 29^{\prime} 13.1^{\prime \prime} \mathrm{N} 36^{\circ} 48^{\prime} 12.1^{\prime \prime} \mathrm{E}$ with the elevation varying between $715 \mathrm{~m}$ and 1,282 $\mathrm{m}$ above sea level (asl), as shown in Fig. 1.

The data used and data sources for this study including the following:

1) Shuttle Radar Topography Mission (SRTM) 1 Arc-Second resolution Digital Elevation Model (DEM)

2) Landsat-8 Operational Land Imager (OLI)

3) Annual rainfall isohyet map from Jordan Ministry of water and Irrigation open files

4) Soil map and data from Jordan Ministry of Agriculture soil mapping system

All these data are processed in the ArcGIS 10.2 software, to prepare the maps used in developing RUSLE equation factors. All map data are processed in the Geographic Coordinate System in raster format with the same spatial resolution (30m x 30m pixel size). The DEM is processed using spatial analysis tools where the watershed boundaries are delineated (Fig. 1), and the geophysical data needed to find the topographic factor (LS) such as slope and flow accumulation are derived.

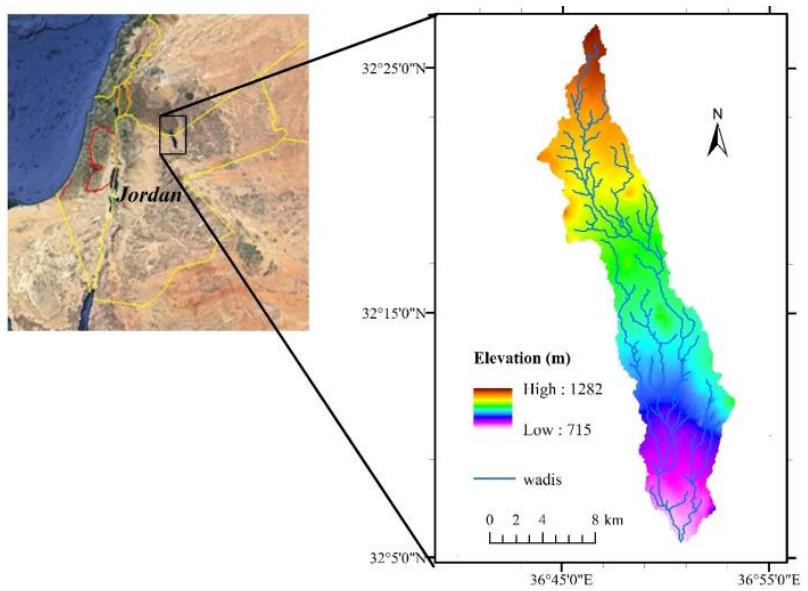

Fig. 1. Location and DEM of Asreh watershed.

The annual rainfall isohyet map was in a vector format; it was converted into a raster format map with the pixel size equal to $30 \mathrm{~m}$ in the study watershed and used in calculating the $\mathrm{R}$ factor. The study area receives annual rainfall varying from less than $50 \mathrm{~mm}$ in its south end to more than $300 \mathrm{~mm}$ in its northern parts (Fig. 2). The rainy season extends mostly between October and April [19].

The soil map in the study area was developed using the soil mapping system at the Jordan Ministry of Agriculture. The soil map and data were provided in vector format with detailed attributes including the grain size and the organic matter content (OMC). The soil in the study area is classified as Loam and Silty Clay Loam, as shown in Table I, with limited OMC. Table I shows that four soil units in the study watershed exist, and Fig. 3 shows the different soil units based on soil texture and OMC.

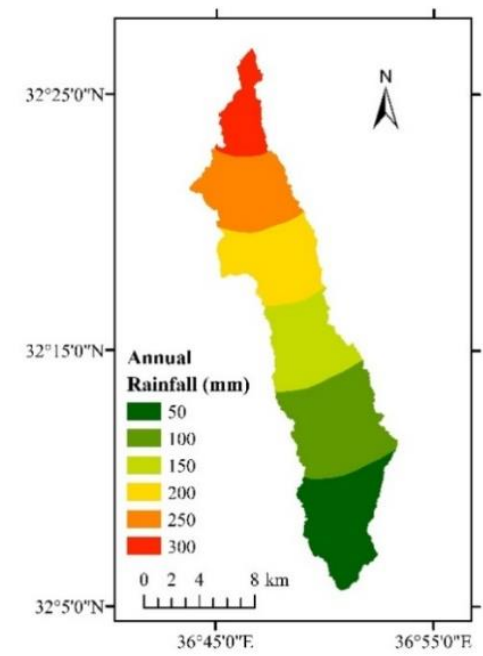

Fig. 2. Annual rainfall in the watershed.

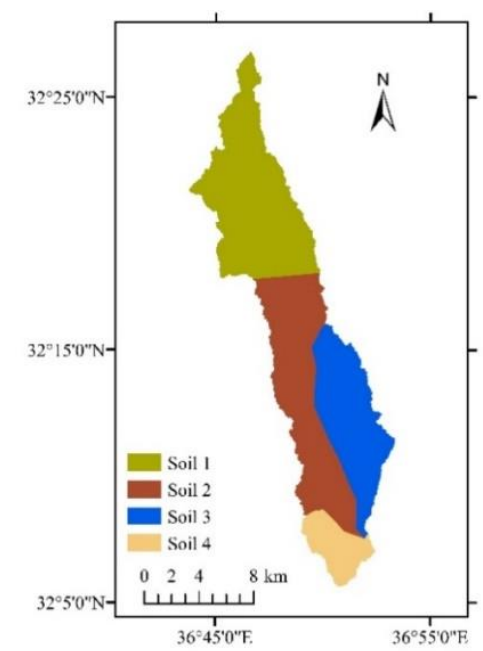

Fig. 3. Soils units in the watershed (as in Table I).

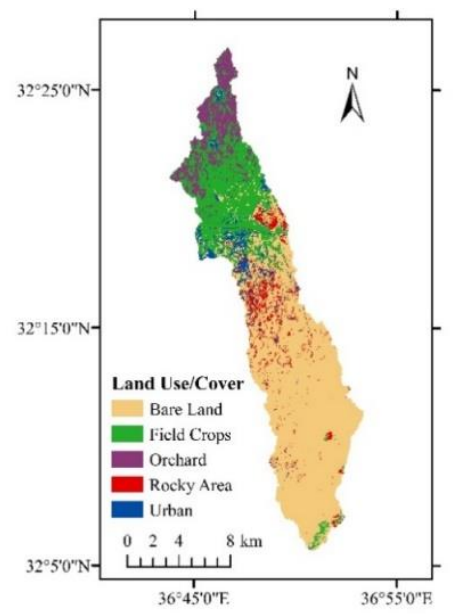

Fig. 4. LULC in the watershed.

The LULC map (Fig. 4) was developed using unsupervised classification of Landsat- 8 OLI bands 3, 4, 5, and 7 combination where the resulting classes are identified using field investigation. Dominated by a relatively high annual rainfall, the northern half of the watershed exhibits agricultural land use, while the southern half is mostly bare land used for livestock grazing [19]. 
Table II summarizes the general data processing steps for calculating and obtaining each of the RUSLE equation factors.

TABLE I: SOILS IN THE STUDY AREA

\begin{tabular}{|c|c|c|c|c|c|}
\hline Soil & Sand $(\%)$ & Silt (\%) & $\begin{array}{l}\text { Clay } \\
(\%) \\
\end{array}$ & $\begin{array}{c}\text { OMC } \\
(\%)\end{array}$ & $\begin{array}{c}\text { Soil } \\
\text { Texture }\end{array}$ \\
\hline Soil 1 & 31.0 & 49.5 & 19.5 & 2 & Loam \\
\hline Soil 2 & 31.0 & 49.5 & 19.5 & 1 & Loam \\
\hline Soil 3 & 20.0 & 51.0 & 29.0 & 1 & $\begin{array}{c}\text { Silty Clay } \\
\text { Loam }\end{array}$ \\
\hline Soil 4 & 35.5 & 44.0 & 20.5 & 1 & Loam \\
\hline
\end{tabular}

TABLE II: RUSLE EQUATION PROCESSES

\begin{tabular}{|c|c|c|c|}
\hline $\begin{array}{c}\text { Data } \\
\text { Type/Source }\end{array}$ & $\begin{array}{c}\text { Preparation } \\
\text { Processes } \\
\end{array}$ & RUSLE Factor & $\begin{array}{c}\text { End } \\
\text { Process }\end{array}$ \\
\hline Annual Rainfall & Isohyet map & $\begin{array}{l}\text { Rainfall erosivity } \\
\text { factor }(R)\end{array}$ & \multirow{4}{*}{$\begin{array}{l}A=R L S \\
K C P \\
\text { Soil loss } \\
\text { map }\end{array}$} \\
\hline $\begin{array}{l}\text { SRTM } 1 \\
\text { Arc-Second } \\
\text { resolution DEM }\end{array}$ & $\begin{array}{l}\text { Flow } \\
\text { direction } \rightarrow \text { Flow } \\
\text { accumulation } \\
\text { Slope }(\%) \rightarrow \text { Slope } \\
\text { (degrees) }\end{array}$ & $\begin{array}{l}\text { Topographic factor } \\
(L S)\end{array}$ & \\
\hline Soil Map & $\begin{array}{l}\text { Soil type \& Soil } \\
\text { organic content }\end{array}$ & $\begin{array}{l}\text { soil Erodibility } \\
\text { factor }(K)\end{array}$ & \\
\hline $\begin{array}{l}\text { Landsat-8 } \\
\text { Satellite Image }\end{array}$ & LULC map & $\begin{array}{l}\text { cover-management } \\
\text { factor }(C) \\
\text { support practice } \\
\text { factor }(P)\end{array}$ & \\
\hline
\end{tabular}

\section{B. RUSLE Model}

Many techniques and approaches were used to analyze and evaluate soil losses in a watershed scale. Most of these approaches used the original Universal Soil Loss Equation (USLE) and later its revised version (RUSLE) [20], [21]. The RUSLE equation is preferred over its original version (USLE) because the input factors are easier to estimate in the revised version. The RUSLE equation calculates the soil erosion as a product of five input factors, namely rainfall erosivity, slope-length, soil erodibility, cover management, and practice factors. Equation (1) presents the RUSLE equation:

$$
A=R \times L S \times K \times C \times P
$$

where:

$A$ is average of soil loss (t/ha.yr),

$R$ is rainfall erosivity factor (MJ.mm/ha.hr.yr),

$L S$ is slope length and steepness factor (dimensionless)

$K$ is soil erodibility factor (t.ha.hr/ha.MJ.mm),

$C$ is cover management factor (dimensionless, ranging between 0 and 1 ), and

$P$ is practices factor (dimensionless, ranging between 0 and $1)$.

\section{1) Rainfall erosivity factor $(R)$}

Different models to find the annual rainfall erosivity factor $(R)$ used in different watersheds exist. Most of the models used the average annual rainfall to calculate the $R$ factor [8], [9], [17], [22]-[26]. Some of the models used the annual average rainfall, the 20 years daily rainfall [27], and the monthly average rainfall [7], [28].

In this study, the model adopted by [22] was used because the available data for the study area are the annual rainfall (Fig. 2), and this model was used in areas with a relatively low annual rainfall similar to the study area. Equation (2) calculates the rainfall erosivity factor using annual rainfall.

$$
R=81.5+0.375 P_{a}
$$

where $P_{a}$ is the annual rainfall $(\mathrm{mm})$, and $R$ is rainfall erosivity factor (MJ.mm/ha.hr.yr).

\section{2) Topographic factor $(L S)$}

The topographic factor $(L S)$ includes two parameters: length of the slope $(L)$ and its inclination $(S)$. These parameters exhibit a significant impact on the runoff volume, speed, and consequently on water erosion. As the length and slope of the watershed increase, the volume and speed of the runoff increase [6], [29], [30].

The original equation of the $L S$ factor was established by [31]. Other researches later modified the original equation, such as [32]-[34]. Equation (3) that has been adopted by many researchers to find the $L S$ factor was used in this study.

$$
L S=(m+1)\left(\frac{U}{22.1}\right)^{m}\left(\frac{\sin \beta}{0.09}\right)^{n}
$$

where $U$ is the upslope contributing area per unit width $\left(\mathrm{m}^{2} / \mathrm{m}\right), \beta$ is the angle of slope in degrees, $m$ is constant related to the type of flow, and $n$ is the constant related to the steepness of the flow. The values of the constants $m$ and $n$ are between (0.2-0.6) and between (1.0-1.3), respectively. A low value of $m$ is for sheet flow and highest for gully flow, and a low value of $n$ is for low slopes and highest for steep slope [30].

\section{3) Soil erodibility factor $(K)$}

The soil erodibility factor $(K)$ represents the soil particles resistance to erosion, due to its intrinsic properties. This resistance depends on soil particles' characteristics and organic matter as well as management techniques such as cultivation and soil stabilization methods [35].

Several methods to find the $K$ factor exist, and it can be calculated using the grain size distribution, organic matters content, and permeability such as in [7], [8], [21], [23], [36]. Other researchers used the soil erodibility nomograph developed by [20] to identify tables for the $K$ values depending on soil characteristics and literature such as [9], [17], [18], [24]-[28].

Equation (4) developed by [34] was used in this study to calculate the soil erodibility factor $(K)$ factor using soil texture and OMC.

$$
\begin{gathered}
K=27.66 \times m^{1.14} \times 10^{-8} \times(12-a)+ \\
0.0043 \times(b-2)+0.0033 \times(c-3)
\end{gathered}
$$

where:

$K=$ soil erodibility factor (t.ha.hr/ha.MJ.mm),

$m=($ silt $(\%)+$ fine sand $(\%)) \times(100-$ clay $(\%))$

$a=$ organic matter $(\%)$

$b=$ structure code varies from 1 for very structured, to 4 for solid

$c=$ profile permeability code varies from (1) for rapid, to (6) for very slow

The soil of the study area is mostly Loam and Silty Loam, as shown in Table I, which indicates that the soil is semi-solid with slow permeability, and for that the values for $b$ and $c$ used in this study are 3 and 5, respectively.

4) Vegetation cover and management factor $(C)$ 
The $C$ factor is a very important factor that affects the potential soil erosion, since it considers the land cover mainly vegetation as a soil stabilization measure. In order to obtain the $C$ factor, vegetation and land cover can be determined using satellite. One of the widely used ways to derive vegetation cover is the use of Normalized Difference Vegetation Index (NDVI) [7], [18], [37]-[39].

The vegetation density and ground cover increase will lead in reducing the soil erosion. A general definition of the $C$ factor is that it is the ratio of soil loss due to water erosion from an area with a specific land cover to that from an area with loose soil with no prevention to water erosion. $C$ ranges between 1 and 0 where the value 1 indicates no vegetation or land cover that could reduce soil erosion due to water runoff, and conversely, the value 0 indicates that dense vegetation or ground cover that protect soil and prevent erosion exists [18], [21], [40]. In this study, assigned values of $C$ from literature for each LULC class was used with Fig. 4 to develop the $C$ factor for the study watershed.

\section{5) Land management factor $(P)$}

The $P$ factor represents specific practices to limit soil loss mainly in slopes. Usually these practices influence the drainage pattern of the area by reducing runoff direction, speed, and pattern. These influences can be done by the way of farming and cultivation along the slope and introducing support structure for the soil such as terraces and gabions.

A simple definition of $P$ factor is the ratio of soil loss with specific support practice to that for soil with tillage along the slope [9], [21]. The values of $P$ factor ranges between 0 and 1 where $P$ equal 1 indicates poor conservation practices, and conversely, a $P$ around 0 indicates good soil conservation practices [41], [42]. To define the values of $P$ factor, assigned values of $P$ from field investigation, and literature for each LULC class was used with Fig. 4 to develop the $P$ factor for the study watershed.

\section{RESULTS AND DISCUSSION}

The RUSLE equation input five factors are calculated and derived for the study watershed as follows:

\section{A. $R$ Factor Map}

The annual rainfall values from Fig. 2 are used to calculate the rainfall erosivity factor $(R)$. Equation (2) was used to calculate the $R$ factor from the annual rainfall raster map (Fig. $2)$, using the raster calculator in ArcGIS software. The results of calculating the $R$ values in raster format are shown in Fig. 5 .

The $R$ factor ranged between 100 in the southern part of the watershed where the annual rainfall is $50 \mathrm{~mm}$ to 194 in the upstream end of the watershed where the annual rainfall is $300 \mathrm{~mm}$. The average value for the $R$ factor in the Asreh watershed equals 140 .

\section{B. LS Factor Map}

The topographic factor $(L S)$ includes two parameters: length of the slope $(L)$ and its inclination $(S)$. Equation (3) was used to calculate the $L S$ factor, using the data derived from the DEM of the study area.

The values for the constants $m$ and $n$ used in this study are 0.6 and 1.3 , respectively. The accumulated pixels were found using the flow accumulation process of the DEM on ArcGIS, and the upslope contributing area $(U)$ map is generated. The slope map was generated from the DEM, and the slope sin $(\sin \beta)$ map is calculated from the slope map. The $L S$ factor map is generated using both $U$ and $\sin \beta$ maps as input to Equation (3).

Fig. 6 shows the values of the $L S$ factor in the Asreh watershed, where most of the area (about $80 \%$ ) exhibits $L S$ values less than 2 and only limited areas (about 9\%) exhibit a $L S$ more than 8 . These values indicate that the slope in the watershed is not steep and demonstrates a limited effect on soil water erosion. Additionally, these values indicate that the watershed size is relatively small, and the upslope contributing areas are limited.

\section{K Factor Map}

Equation (4), defined before, is used to calculate the $K$ factor using soil particles sizes and OMC in the study watershed (Table I).

The $K$ factor values in the Asreh watershed were very close, since not much of variation between the soil types within the watershed occurred. The soil is mostly dominated by Loam giving values for $K$ factor that varied from 0.050 to 0.057 , as shown in Fig. 7.

\section{C Factor Map}

The $C$ factor represents the vegetation density and ground cover that limits the soil erosion due to water runoff. The LULC map for the Asreh watershed (Fig. 4) is used to estimate the values of $C$ factor. The values of the $C$ factor were assigned according to the literature for each LULC class in the study watershed. The following three groups of LULC exist: the bare land, agriculture land, and urban and rocky areas. As shown in Fig. 8, the values of $C$ varied between 0.3 in urban and rocky areas to 0.8 for bare land, which forms most of the watershed area with the agricultural areas exhibiting a $C$ factor of 0.5 .

\section{E. P factor map}

The $\mathrm{P}$ factor represents the practices that prevent soil erosion. Limited data on the types of practices exist on the study area, except the LULC. The LULC map for the Asreh watershed (Fig. 4) is used to estimate the values of $P$ factor for the different LULC. The values of $P$ factor were assigned according to the literature for each LULC class in the study watershed. Two groups of LULC exist: the agriculture land and other areas. The agriculture was developed for a long time in the area, and good farming practices exist with measures to protect soil in the orchard fields such as stone walls. In the field crops areas, the plowing is usually against a slope with small stone walls that limit the runoff speed within these fields. These practices lead to assigning a value for the $P$ factor as 0.3 in the agriculture land, and for the other areas that exhibits no practices, the assigned value of $P$ is 1.0 , as shown in Fig. 9.

\section{F. Soil Loss Rate Map}

The five factors for the RUSLE equations were prepared in the form of raster format with the same resolution (Fig. 5 to 9). Using the raster calculator in ArcGIS, these five factors were multiplied, as shown in (1), to find the soil loss rate in t/ha.yr. The resulting map for the soil loss rate is shown in Fig. 
10. The values of soil loss rate are classified into three classes: the low soil loss (less than 10 t/ha.yr), the moderate soil loss (10 to $20 \mathrm{t} / \mathrm{ha} . \mathrm{yr}$ ), and the high soil loss (more than 20 t/ha.yr).

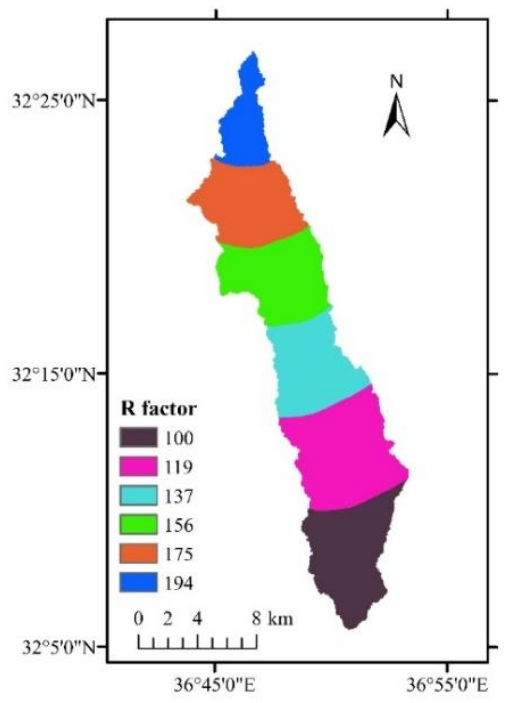

Fig. 5. R factor.

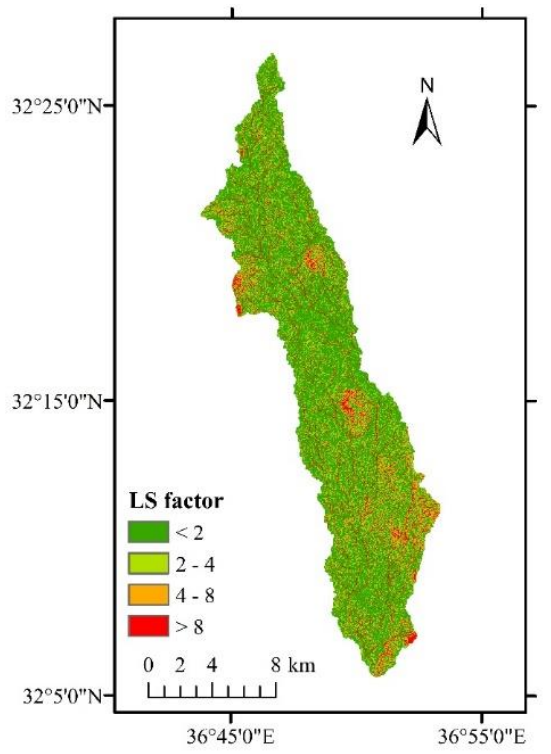

Fig. 6. LS factor.

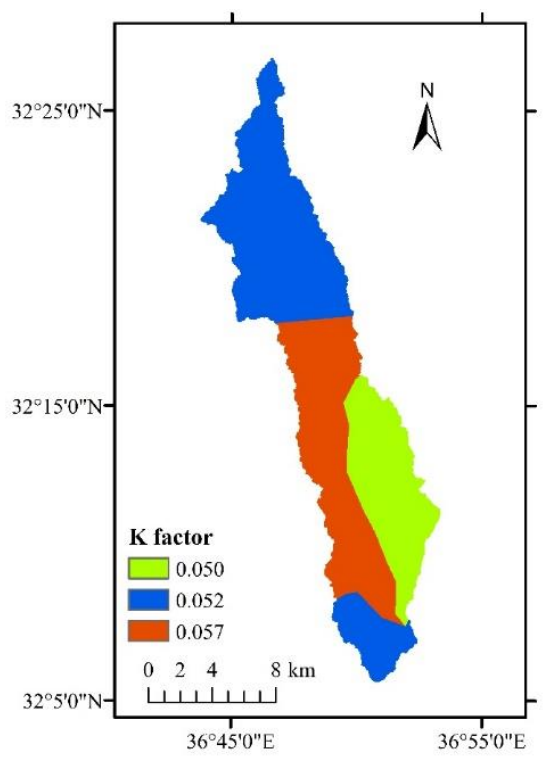

Fig. 7. $\mathrm{K}$ factor.

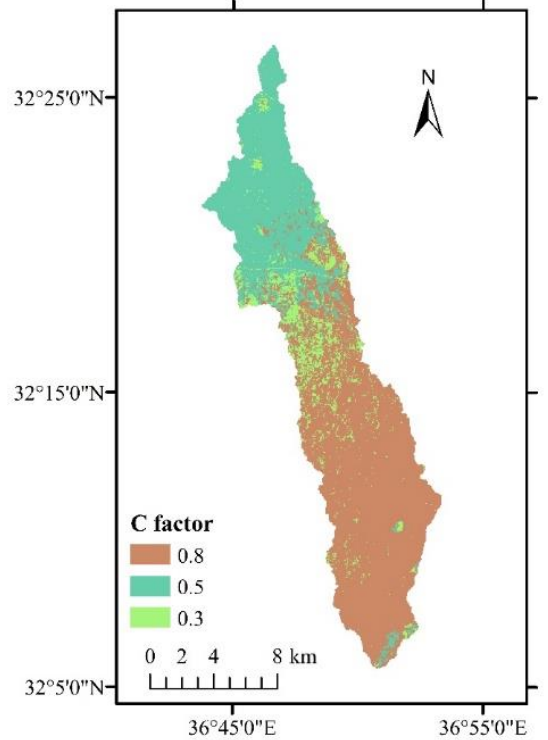

Fig. 8. C factor.

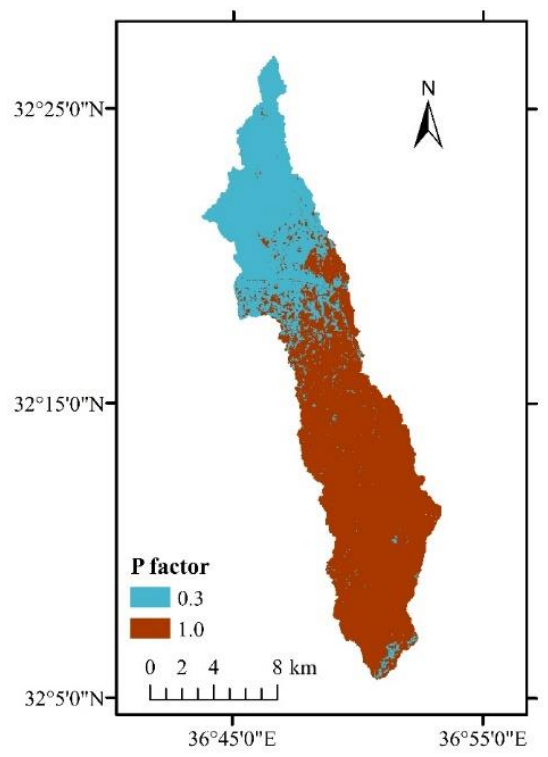

Fig. 9. P factor.

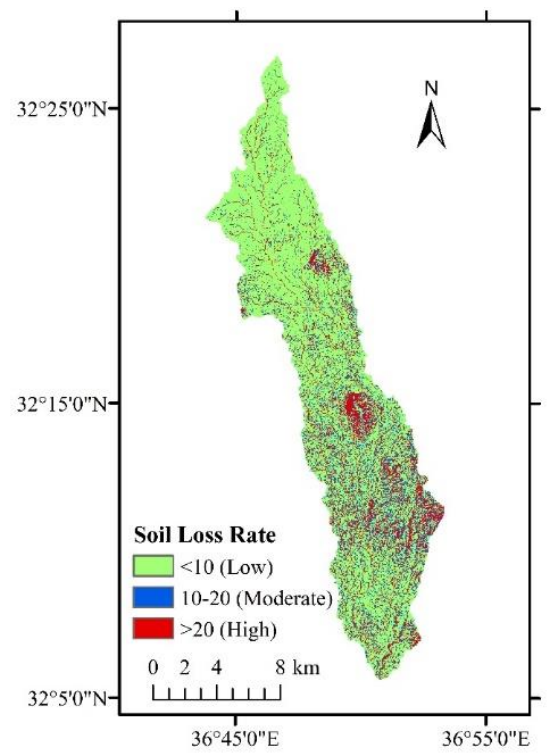

Fig. 10. Soil loss rate

The share of each class of the soil loss rate are listed in Table III, and the average soil loss rate in the Asreh 
watershed was found to be $7.8 \mathrm{t} / \mathrm{ha}$.yr excluding the soil loss rate values in the main water courses (wadis), which leads to an estimated soil loss from the watershed of about 153,000 t/yr.

TABLE III: SOIL LOSS RATES AND CLASSES FOR THE ASREH WATERSHED

\begin{tabular}{ccc}
\hline Soil Loss Rate (t/ha.yr) & Classification & Area, $\mathrm{km}^{2}(\%)$ \\
\hline$<10$ & Low & $143.1(73 \%)$ \\
$10-20$ & Moderate & $27.4(14 \%)$ \\
$>20$ & High & $25.5(13 \%)$ \\
TOTAL & & $196(100 \%)$ \\
\hline \hline
\end{tabular}

\section{CONCLUSION}

The RUSLE equation is a widely used tool to assess soil loss rates due to rainfall runoff at a watershed scale. The Asreh watershed that is $196 \mathrm{~km}^{2}$ was studied, to estimate the soil loss rate and map the areas with different soil loss classification. The rainfall in the Asreh watershed varied between 50 and $300 \mathrm{~mm}$ per year, resulting in an $R$ factor between 100 and 194 with an average of 140 . On the same extent, the topographic factor, $L S$, is less than 2 in about $80 \%$ of the area, since the topography is characterized by a gentle slope in most of the area, and the watershed size is relatively small. The soil factor, $K$, is not varied largely because the soil in the watershed is dominated by Loam, and its values varied between 0.05 and 0.057 . Vegetation and land cover were generated using RS data, and the LULC in the watershed was found to exhibit the following classes: cultivation including field crops and orchards, urban areas, bare lands, and lands covered with rocks. The vegetation cover factor, $C$, was found for three groups of LULC: the cultivated areas with the assigned $C$ value as 0.5 , bare land with the assigned $C$ value as 0.8 , and urban and rocky areas with the assigned $C$ value as 0.3 . The $P$ factor values were assigned using the LULC classes. The farming areas exhibit some soil protection practices, and a value of 0.3 was assigned for $P$ factor. Conversely, the other LULC classes exhibit no practices to prevent soil from erosion, and a $P$ value of 1.0 was assigned for these classes.

Processing the five RUSLE equation parameters in ArcGIS resulted in a raster map for the soil loss rate in the Asreh watershed. The soil loss rates were classified into three classes: low soil loss (less than $10 \mathrm{t} / \mathrm{ha}$.yr), moderate soil loss (10-20 t/ha.yr), and high soil loss (more than $20 \mathrm{t} / \mathrm{ha} . \mathrm{yr}$ ). Most of the area (about 73\%) exhibits a low soil loss rate, $14 \%$ exhibits a moderate soil loss rate, and only $13 \%$ exhibits a high soil loss rate. The high soil loss rates were mostly close to the main water courses where the topographic factor $(L S)$ demonstrates high values and in some areas was associated with high slopes in bare lands. The average soil loss rate for the Asreh watershed was found to be around $7.8 \mathrm{t} / \mathrm{ha}$.yr, and this average demonstrates that the watershed drains about 153,000 tons of sediments per year into the dam.

The resulted RUSLE map for the watershed can help in assessing best watershed management to reduce soil erosion in the high soil loss rate areas, these practices will reduce the sediments in the dam reservoir and increase its effective storage and also reduce the cost of maintaining the dam reservoir. The next research will be measuring the sediments volumes in the dam reservoir and perform sensitive analysis of the RUSLE model factors in the study watershed.

\section{CONFLICT OF INTEREST}

The author declares no conflict of interest.

\section{AUTHOR CONTRIBUTIONS}

Saad M. AlAyyash conducted the research, analyzed the data, prepared the manuscript and approved the final version,

\section{ACKNOWLEDGMENT}

This research was carried out by Saad M. AlAyyash while on sabbatical leave from Al al-Bayt University for the academic year (2018/2019). The author appreciates the support from Al al-Bayt University president and deans' council members.

\section{REFERENCES}

[1] M. Al-Farajat et al., "Preliminary geophysical investigation for suggested water harvesting sites in the Northern Jordanian Badia," Research Journal of Environmental and Earth Sciences, vol. 4, no. 5, pp. 560-569, May 2012.

[2] N. Hadadin, "Dams in Jordan current and future perspective," Canadian Journal of Pure and Applied Sciences, vol. 9, no. 1, pp. 3279-3290, 2015.

[3] K. AlMassaied et al., "Water resources management at Marab Hassan-NE Badia/Jordan," Asian Journal of Agricultural Sciences, vol. 4, no. 1, pp. 65-71, Jan. 2012.

[4] R. Benavidez et al., "A review of the (revised) universal soil loss equation ((R) USLE): With a view to increasing its global applicability and improving soil loss estimates," Hydrology and Earth System Sciences, vol. 22, no. 11, pp. 6059-6086, 2018.

[5] K. G. Renard et al., "8 Universal soil loss equation and revised universal soil loss equation," Handbook of erosion modelling, 2011, pp. 135-167.

[6] G. Singh and R. K. Panda, "Grid-cell based assessment of soil erosion potential for identification of critical erosion prone areas using USLE, GIS and remote sensing: A case study in the Kapgari watershed, India,' International Soil and Water Conservation Research, vol. 5, no. 3, pp. 202-211, Sep. 2017.

[7] B. P. Ganasri and H. Ramesh, "Assessment of soil erosion by RUSLE model using remote sensing and GIS-A case study of Nethravathi Basin," Geoscience Frontiers, vol. 7, no. 6, pp. 953-961, Nov. 2016.

[8] K. Balasubramani et al., "Estimation of soil erosion in a semi-arid watershed of Tamil Nadu (India) using revised universal soil loss equation (RUSLE) model through GIS," Modeling Earth Systems and Environment, vol. 1, no. 3, p. 10, Oct. 2015.

[9] T. G. Pham et al., "Integrated universal soil loss equation (USLE) and Geographical Information System (GIS) for soil erosion estimation in A sap basin: Central Vietnam," International Soil and Water Conservation Research, vol. 6, no. 2, pp. 99-110, June 2018.

[10] L. Duarte et al., "Assessing soil erosion risk using RUSLE through a GIS open source desktop and web application," Environmental Monitoring and Assessment, vol. 188, no. 6, p. 351, June 2016.

[11] G. Dumedah et al., "Spatial targeting of soil loss using RUSLE in GIS: The case of Asokore Mampong municipality, Ghana," Journal of Applied Geospatial Information, vol. 3, no. 1, pp. 166-172, Jan. 2019.

[12] I. Gaubi et al., "A GIS-based soil erosion prediction using the revised universal soil loss equation (RUSLE) (Lebna watershed, Cap Bon, Tunisia)," Natural Hazards, vol. 86, no. 1, pp. 219-239, Mar. 2017.

[13] M. Zerihun et al., "Assessment of soil erosion using RUSLE, GIS and remote sensing in NW Ethiopia," Geoderma regional, vol. 12, pp. 83-90, Mar. 2018.

[14] J. Thomas, S. Joseph, and K. P. Thrivikramji, “Assessment of soil erosion in a tropical mountain river basin of the southern Western Ghats, India using RUSLE and GIS," Geoscience Frontiers, vol. 9, no. 3, pp. 893-906, May 2018.

[15] E. R. Cunha, V. M. Bacani, and E. Panachuki, "Modeling soil erosion using RUSLE and GIS in a watershed occupied by rural settlement in the Brazilian Cerrado," Natural Hazards, vol. 85, no. 2, pp. 851-868, Jan. 2017.

[16] H. Abdo and J. Salloum, "Mapping the soil loss in Marqya basin: Syria using RUSLE model in GIS and RS techniques," Environmental Earth Sciences, vol. 76, no. 3, p. 114, Feb. 2017.

[17] S. Biswas, "Estimation of soil erosion using remote sensing and GIS and prioritization of catchments," International Journal of Emerging 
Technology and Advanced Engineering, vol. 2, no. 7, pp. 124-128, July 2012.

[18] R. Parveen and U. Kumar, "Integrated approach of universal soil loss equation (USLE) and geographical information system (GIS) for soil loss risk assessment in Upper South Koel Basin, Jharkhand," Journal of Geographic Information System, vol. 4, no. 6, pp. 588-596, Dec. 2012.

[19] A. A. R. Al-Shabeeb et al., "Delineating groundwater potential zones within the Azraq Basin of Central Jordan using multi-criteria GIS analysis," Groundwater for Sustainable Development, vol. 7, pp. 82-90, Sep. 2018.

[20] W. H. Wischmeier et al., "A soil erodibility nomograph for farmland and construction sites," Journal of Soil and Water Conservation, vol. 26, pp. 189-193, 1971.

[21] K. G. Renard et al., "Predicting soil erosion by water: A guide to conservation planning with the revised universal soil loss equation (RUSLE)," USDA Agricultural Handbook No. 703, pp. 126-131, 1997.

[22] N. Kayet et al., "Evaluation of soil loss estimation using the RUSLE model and SCS-CN method in hillslope mining areas," International Soil and Water Conservation Research, vol. 6, no. 1, pp. 31-42, Mar. 2018.

[23] L. Tamene et al., "Estimating landscape susceptibility to soil erosion using a GIS-based approach in Northern Ethiopia," International Soil and Water Conservation Research, vol. 5, no. 3, pp. 221-230, Sep. 2017.

[24] H. S. Gelagay and A. S. Minale, "Soil loss estimation using GIS and Remote sensing techniques: A case of Koga watershed, Northwestern Ethiopia," International Soil and Water Conservation Research, vol. 4 no. 2, pp. 126-136, June 2016.

[25] C. P. Devatha et al., "Estimation of soil loss using USLE model for Kulhan Watershed, Chattisgarh - A case study," Aquatic Procedia, vol. 4, pp. 1429-1436, Jan. 2015.

[26] T. Chandramohan and D. G. Durbude, "Estimation of soil erosion potential using universal soil loss equation," Journal of the Indian Society of Remote Sensing, vol. 30, no. 4, pp. 181-190, Dec. 2002.

[27] H. Bouguerra et al., "Mapping erosion prone areas in the Bouhamdane watershed (Algeria) using the revised universal soil loss equation through GIS," Journal of Water and Land Development, vol. 32, no. 1 , pp. 13-23, Mar. 2017.

[28] V. Prasannakumar et al., "Estimation of soil erosion risk within a small mountainous sub-watershed in Kerala, India, using Revised Universal Soil Loss Equation (RUSLE) and geo-information technology," Geoscience Frontiers, vol. 3, no. 2, pp. 209-215, Mar. 2012.

[29] H. Zhang et al., "An improved method for calculating slope length $(\lambda)$ and the LS parameters of the revised universal soil loss equation for large watersheds," Geoderma, vol. 308, pp. 36-45, Dec. 2017.

[30] P. Panagos, P. Borrelli, and K. Meusburger, "A new European slope length and steepness factor (LS-Factor) for modeling soil erosion by water," Geosciences, vol. 5, no. 2, pp. 117-126, June 2015.

[31] W. H. Wischmeier and D. D. Smith, "Predicting rainfall-erosion losses from cropland east of the Rocky Mountains: Guide for selection of practices for soil and water conservation (No. 282)," US Department of Agriculture, 1965.

[32] I. D. Moore and J. P. Wilson, "Length-slope factors for the revised universal soil loss equation: Simplified method of estimation," Journal of Soil and Water Conservation, vol. 47, no. 5, pp. 423-428, Sep. 1992.
[33] I. D. Moore and G. J. Burch, "Physical basis of the length-slope factor in the universal soil loss equation 1," Soil Science Society of America Journal, vol. 50, no. 5, pp. 1294-1298, 1986.

[34] W. H. Wischmeier and D. D. Smith, "Predicting rainfall erosion losses: a guide to conservation planning (No. 537)," US Department of Agriculture, Science and Education Administration, 1978.

[35] K. Auerswald, P. Fiener, W. Martin, and D. Elhaus, "Use and misuse of the $\mathrm{K}$ factor equation in soil erosion modeling: An alternative equation for determining USLE nomograph soil erodibility values," Catena, vol. 118, pp. 220-225, July 2014.

[36] P. Panagos et al., "Soil erodibility in Europe: A high-resolution dataset based on LUCAS," Science of the Total Environment, vol. 479, pp. 189-200, May 2014.

[37] L. Tadesse et al., "Land use and land cover changes and Soil erosion in Yezat Watershed, North Western Ethiopia," International Soil and Water Conservation Research, vol. 5, no. 2, pp. 85-94, June 2017.

[38] V. L. Durigon et al., "NDVI time series for monitoring RUSLE cover management factor in a tropical watershed," International Journal of Remote Sensing, vol. 35, no. 2, pp. 441-453, Jan. 2014.

[39] A. Karaburun, "Estimation of C factor for soil erosion modeling using NDVI in Buyukcekmece watershed," Ozean Journal of Applied Sciences, vol. 3, no. 1, pp. 77-85, 2010.

[40] J. Biesemans et al., "Extending the RUSLE with the Monte Carlo error propagation technique to predict long-term average off-site sediment accumulation," Journal of Soil and Water Conservation, vol. 55, no. 1, pp. 35-42, Jan. 2000.

[41] P. Panagos et al., "Estimating the soil erosion cover-management factor at the European scale," Land Use Policy, vol. 48, pp. 38-50, Nov. 2015.

[42] A. H. Abdel-Magid et al., "Soil and vegetation responses to simulated trampling," Rangeland Ecology \& Management/Journal of Range Management Archives, vol. 40, no. 4, pp. 303-306, July 1987.

Copyright $(\odot 2021$ by the authors. This is an open access article distributed under the Creative Commons Attribution License which permits unrestricted use, distribution, and reproduction in any medium, provided the original work is properly cited (CC BY 4.0).

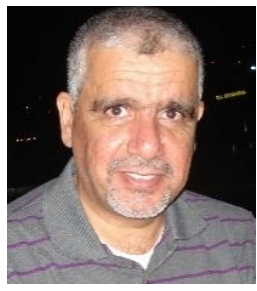

Saad M. AlAyyash was born in Jordan on the 4th of July 1967. He received his BSc in civil engineering from Jordan University of Science and Technology, Jordan in 1990, his MSc in civil engineering from Jordan University of Science and Technology, Jordan in 1993 and his $\mathrm{PhD}$ in the surface water modeling in arid lands of Jordan using GIS from University of Central Florida, USA in 2002 .

He is currently an associate professor in the field of water and environment engineering at the civil engineering department, college of engineering, $\mathrm{Al}$ al-Bayt University. His current research interests include arid land hydrologic modelling, sustainable watershed management and development. 